\title{
DA REVOLUÇÃO INACABADA À GUERRA ÉTICA: BENSAÏD COMO DEFENSOR E CRÍTICO DOS DIREITOS HUMANOS
}

FROM THE UNFINISHED REVOLUTION TO THE ETHICAL WAR: BENSAÏD AS A DEFENDER AND CRITIC OF HUMAN RIGHTS

DE LA RÉVOLUTION INACHEVÉE À LA GUERRE ÉTHIQUE: BENSAÏD COMME DÉFENSEUR ET CRITIQUE DES DROITS DE L'HOMME

DE LA REVOLUCIÓN INCONCLUSA A LA GUERRA ÉTICA: BENSAÏD COMO DEFENSOR Y CRÍTICO DE LOS DERECHOS HUMANOS

Gustavo Seferian* http://orcid.com/0000-0002-5587-6734

RESUMO: O presente artigo pretende abordar a obra de Daniel Bensaïd expondo os principais indutores de reflexão e contribuições críticas ao uso instrumental dos Direitos Humanos. Utilizando-nos do repertório dedutivo, e pautando-nos no revolvimento textual de autoria do militante-filósofo, o artigo ( $i$ ) demonstra como o tema dos Direitos Humanos atravessa a obra de Bensaïd, marcado pela conjuntura e se articulando com outros grandes temas de sua vida, expondo as bases elementares de sua formulação; (ii) evidencia o quanto os Direitos Humanos são percebidos em sua obra como uma promessa burguesa inconclusa, que reclamam seu reconhecimento enquanto marco progressivo, ao mesmo tempo que limitado, da disputa política na modernidade; (iii) destaca como tal se manifestou no transcurso da Revolução Francesa no particular tocante às e aos não-proprietários, escravizados e mulheres; sinalizando ainda (iv) o modo como em momentos sócio-históricos distintos a defesa dos Direitos Humanos é instrumentalizada como modo de afirmação imperialista, reclamando particulares e cuidadosas abordagens na contemporaneidade, sobretudo ante a escalada do que chamou de "guerra ética".

\footnotetext{
* Doutor em Direito do Trabalho; Professor do Departamento de Direito do Trabalho da Universidade
} Federal de Minas Gerais (UFMG), Belo Horizonte, MG, Brasil; E-mail: seferian@ufmg.br 
Da revolução inacabada à guerra ética: Bensaïd como defensor e crítico dos direitos humanos.

Palavras-chave: Daniel Bensaïd; Direitos Humanos; Universalidade; Revolução Francesa; Guerra ética.

ABSTRACT: This article intends to approach the work of Daniel Bensaïd exposing the main reflections and critical contributions to the instrumental use of Human Rights. Using the deductive repertoire, and based on the textual revision by the militant-philosopher, the article (i) demonstrates how the theme of Human Rights crosses the work of Bensaï, marked by the conjuncture and articulating with other great themes of his life, exposing the elementary bases of his formulation; (ii) it shows how much Human Rights are perceived in his work as an unfinished bourgeois promise, which demand its recognition as a progressive, at the same time limited, landmark of the political dispute in modernity; (iii) highlights how it manifested itself in the course of the French Revolution in particular with regard to non-owners, enslaved and women; also signaling (iv) the way in which at different socio-historical moments the defense of Human Rights is instrumentalized as a way of imperialist affirmation, demanding particular and careful approaches in contemporary times, especially in view of the escalation of what he called "ethical war".

Keywords: Daniel Bensaïd; Human rights; Universality; French Revolution; Ethical war.

RÉSUMÉ: Cet article entend aborder le travail de Daniel Bensaïd en exposant les principaux inducteurs de réflexion et contributions critiques à l'utilisation instrumentale des Droits de l'Homme. Utilisant le répertoire déductif, et basé sur la révision textuelle du philosophe-militant, l'article (i) montre comment le thème des Droits de l'Homme traverse l'œuvre de Bensaïd, marqué par la conjoncture et s'articulant avec d'autres grands thèmes de sa vie, exposant les bases élémentaires de sa formulation; (ii) montre à quel point les Droits de l'Homme sont perçus dans son ouvre comme une promesse bourgeoise inachevée, qui exige sa reconnaissance comme un jalon progressif, en même temps limité, du conflit politique dans la modernité; (iii) souligne comment elle s'est manifestée au cours de la Révolution française, en particulier à l'égard des non-propriétaires, des esclaves et des femmes; signalant également (iv) la manière dont, à différents moments socio-historiques, la défense des droits de l'homme est instrumentalisée comme un moyen d'affirmation impérialiste, exigeant des approches particulières et prudentes à l'époque contemporaine, en particulier compte tenu de l'escalade de ce qu'il a appelé la 'guerre éthique'. 
Mots-clés: Daniel Bensaïd; Droits de l'homme; Universalité; Révolution française; Guerre éthique.

RESUMEN: Este artículo intenta abordar el trabajo de Daniel Bensaïd exponiendo los principales inductores de reflexión y contribuciones criticas al uso instrumental de los Derechos Humanos. Utilizando el repertorio deductivo, y basado en la revisión textual del filósofo militante, el artículo (i) demuestra cómo el tema de los Derechos Humanos cruza el trabajo de Bensaïd, marcado por la coyuntura y la articulación con otros grandes temas de su vida, exponiendo las bases elementales de su formulación; (ii) muestra cuánto se perciben los Derechos Humanos en su trabajo como una promesa burguesa inacabada, que exige su reconocimiento como un hito progresivo, al mismo tiempo limitado, de la disputa política en la modernidad; (iii) destaca cómo se manifestó en el curso de la Revolución francesa, en particular con respecto a las e los no propietarios, esclavos y mujeres; señalando también (iv) la forma en que en diferentes momentos sociohistóricos la defensa de los derechos humanos se instrumentaliza como una forma de afirmación imperialista, exigiendo enfoques particulares y cuidadosos en los tiempos contemporáneos, especialmente en vista de la escalada de lo que él llamó "guerra ética".

Palabras-clave: Daniel Bensaï; Derechos humanos; Universalidad; Revolucion francesa; Guerra ética.

\footnotetext{
"Eu me lembro falam na Declaração Que nascemos livres, livres por iguais! Mas não entendo se escolhemos Ou se alguém escolheu por nós Não está certo, alguns tão ricos Outros não tem nem um amigo..." - Cólera, Direitos Humanos
}

\section{INTRODUÇÃO}

Ainda pouco conhecido no Brasil - sobretudo quando tomamos o vulto de sua obra e as constantes preocupações políticas que, no curso de sua vida, o autor teve com o país ${ }^{1}$-, tendo suas formulações assi-

1 Como militante da IV Internacional, cumpriu Daniel Bensaïd uma série de tarefas de articulação e formulação sobre a realidade latino-americana, bem como a brasileira em particular. O fato se 
miladas basicamente por um reduzido corpo de militantes de tradições trotskistas $^{2}$ e alguns intelectuais no campo da filosofia e sociologia, Daniel Bensaïd é por certo um dos grandes pensadores da segunda metade do século XX e do ainda nascente século XXI, muito embora deste tenha apenas experimentado em vida sua primeira metade.

Filósofo de rara criatividade, em larga medida impulsionada por sua incansável preocupação revolucionária e ação militante, Bensaïd alçou com suas reflexões uma série de problemas à qualidade de temas de vida. Juntamente com a estratégia revolucionária e o partido, a temporalidade dos processos sociais, a crítica à cientificidade burguesa - seja em suas expressões positivas ou pós-modernas -, o enfrentamento às opressões desde uma perspectiva classista e a popularização da obra de Karl Marx, exsurge o tema da gênese, efetividade e instrumentalização dos Direitos Humanos - tomados aqui tanto aqueles civis, políticos e sociais - como um dos grandes objetos de investida de sua obra monumental.

Discutindo este último ponto, buscamos com o presente escrito contribuir com a recepção da obra do autor no país no momento em que nos toca a efeméride dos dez anos de seu falecimento, dado em 12 de janeiro de 2010. Utilizando-nos do repertório dedutivo, e pautando-nos no revolvimento textual de autoria de Daniel Bensaïd, buscaremos então traçar um panorama das suas discussões político-jurídicas calcadas na problemática do que chamamos de uso instrumental dos Direitos Humanos. Ou seja, sua invocação para estancamento dos processos revolucionários, ou, mais grave, para salvaguarda de sua negação pela afirmação capitalista.

mostra sintomaticamente pelas constantes menções ao Brasil no transcorrer de sua obra, tendo dedicado em sua auto-biografia, ela toda repleta de anedotas e poemas brasileiros, um capítulo todo à sua experiência no país, de título “E agora, Zé?" (Bensaïd, 2004, p. 294-329). Explicita bem o fato, sob outra perspectiva, o capítulo elaborado pelo economista e dirigente da Comuna João Machado Borges Neto - o João Machado,(2012) -, em memória de Bensaïd.

2 A referência, feita no plural, remete à acertada compreensão exposta por Bensaïd (2007c) de que o conjunto militante que reivindica o legado de León Trotsky não é unitário, e sim bastante plural, diverso, sendo impossível caracterizá-lo de modo unitário. Em suas palavras: "Se, no singular, o trotskismo remete para uma origem histórica comum, o termo serviu demasiado para ser utilizado sem um prudente plural. A partir da bagagem programática constituída por Trotsky entre as duas guerras, os acontecimentos maiores do século produziram diferenciações tais que o que distingue e opõe as diferentes correntes saídas do "trotskismo" é por vezes tão ou mais importante do que o que as aproxima. Em termos de herança, a piedade filial nem sempre é a melhor prova de fidelidade e há frequentemente mais fidelidade na infidelidade crítica do que na beatice dogmática. É, portanto, mais conforme à realidade falar em trotskismos no plural, em vez de do trotskismo no singular." (Bensaïd, 2007c, p.15-16) 
A especificação quanto ao trato temático se faz indispensável, e desde logo, tendo em vista que no transcorrer se sua vasta obra o militante-filósofo tratou de temas outros correlatos aos Direitos Humanos, bem como à juridicidade em geral - a exemplo das discussões sobre as teorias da justiça, o direito natural, a lida jurídica da propriedade, sua violência instituidora e mantenedora, a prática dos tribunais internacionais etc, servindo até mesmo um processo como espinha dorsal de uma das suas grandes obras(Bensaïd, 1991)! -, cuja discussão comportaria esforço de fôlego maior do que o dispensado a um artigo. Aqui, nossa preocupação se voltará mormente às nuances ideológicas que remetem ao tema, sobretudo em sua defesa mitigada e na sua falsa apologética.

Deste modo, intentamos com a exposição (i) demonstrar como o tema dos Direitos Humanos atravessa a obra de Bensaïd em diversos momentos da sua trajetória intelectual e militante, marcado pelos sabores da conjuntura e se articulando com outros grandes temas de sua vida, expondo as bases elementares de sua formulação; (ii) evidenciar o quanto os Direitos Humanos são percebidos em sua obra como uma promessa burguesa inconclusa, e que assume outras colorações que reclamam seu reconhecimento enquanto marco progressivo, ao mesmo tempo que limitado, da disputa política na modernidade; (iii) destacando como tal se manifestou no transcurso da mais que bicentenária Revolução Francesa no particular tocante às e aos não-proprietários, escravizados e mulheres; sinalizando ainda, a agudizar estas contradições, (iv) o modo como em momentos sócio-históricos distintos a defesa dos Direitos Humanos é instrumentalizada como modo de afirmação imperialista, reclamando particulares e cuidadosas abordagens na contemporaneidade, sobretudo ante a escalada do que chamou de "guerra ética".

\section{BASES REFLEXIVAS DA TOMADA DOS DIREITOS HU- MANOS COMO UM TEMA DE VIDA}

Primeiramente, como exposto, nos parece conveniente evidenciar o quanto a temática dos Direitos Humanos permeou a vida de Daniel Bensaïd como objeto de problematização, crítica e cir- 
cunstancial endosso, articulando-se com outras grandes questões sobre as quais se debruçou. Para tanto, nesta etapa tomaremos as evidências que sintomaticamente despontam de sua autobiografia (Bensaïd, 2004), bem como de textos e entrevistas por si conferidas no curso de sua vida.

Assumido este fio condutor, destacamos que são diversas as menções que Bensaïd traz em Une lente impatiance sobre os Direitos Humanos. Curiosamente, em grande parte delas se pode perceber tons da crítica à instrumentalidade de sua defesa pela ordem social do capital - ponto que pretendemos evidenciar com o artigo -, já que invariavelmente notados em discursos que, no fundo, não buscavam a concretização deste repertório de conquistas sociais, mas sim a salvaguarda dos interesses econômicos e políticos burgueses.

Seu conjunto de preocupações remete, porém, a fundamentos históricos que antecedem em muito a política internacional e francesa por si testemunhadas. Ou seja, precedem seu tempo em vida. Daí podermos perceber que revolveu vasta bibliografia para formar suas compreensões sobre o tema, tomando por amparo as bases constitutivas e revolucionárias (burguesas) dos Direitos Humanos, bem como sua crítica lançada pelo jovem Marx, substrato elementar que esteia grande parte de suas reflexões sobre o tema.

Como questão de concepção, reconhece que o conjunto de Direitos Humanos - tratando especificamente dos Direitos Sociais - foram historicamente conquistados (Bensaïd, 2004, p. 99), sendo, $\operatorname{logo}$, fruto do processo de luta de classe. Não à toa, olhando para o século XX, destaque tais conquistas como marcos relevantes da afirmação humana, contrapostas a expressões de barbárie do período:

On peut faire autrement la part des choses. Le terrible siècle des extremes fut aussi un siècle de contrastes. Il a vu la chut de plusieurs empires coloniaux et continentaux (l'empire tsariste, l'empire ottoman, le britannique le français, le belge, le hollandais, le japonais). Il a proclame l'universalité des droits, reconnu l'égalité de príncipe entre les races et les sexes, condamné les crimes contre l'humanité. Il y a encore loin des príncipes à la réalité, mais rares sont ceux qui osent ouvertement les récuser, de sorte qu'ils constituent um pont d'appui contre l'état réel des choses. (Bensaïd, 2004, p. 460) 
Em outra obra de sua autoria, bastante mais romanceada e que a protagonista em muito - para não dizer em tudo! - expressa suas opiniões, afirma:

Peux-tu imaginer mes grandes joies? Celle du 4 août 1789, jour de l'abolition des privilèges; et celle du 15 mars 1790, jour de l'abolition du servage; et celle du 29 septembre 1791, jou ou le droit de cité fut reconnu aux juifs de l'Est; et celle du 4 février 1794, lors de l'abolition de l'esclavage...Sans parler de la proclamation de la République... (Bensaïd, 1989, p. 36)

Reconhecido seu caráter histórico e sua marca progressiva limitada - visto se tratarem de conquistas "necessárias, mas insuficientes" (Bensaïd, 2010a, p. 87) -, Bensaïd não enfrenta o tema de modo ingênuo e unifacetado, mas sim forma erudita, complexa e atenta. Sem jamais deixar de reconhecer e criticar os limites absolutos do legalismo reformista na ação política (Bensaïd, 1976; 1999c), trata dos direitos civis e políticos prometidos pela burguesia de forma cuidadosa e potente.

Grande parte desta potência resulta da tomada de formulações de Marx em Sobre a questão judaica, que proporciona expor sua convicção quanto a disputa de formas e sentidos - dentre os quais o do direito, inclusive aqueles civis e políticos que constituem o repertório fundamental dos Direitos Humanos da ordem burgue$\mathrm{sa}^{3}$ - como parte formativa da luta política revolucionária, ainda que sabendo seu contido efeito para sozinhos promoverem alterações radicais na sociedade capitalista.

Nas palavras de Bensaïd (2010c, p.17), para Marx “a 'questão judaica' é simplesmente a oportunidade e o pretexto para explorar os limites da emancipação política e para realizar sua crítica do Estado político". Aponta assim, tratando dos direitos do cidadão, que "juriste de formation, il [Marx] savait trop bien que les formes ne sont pas 3 Tratando de período distinto, Isabelle Garo (2010, p.45-46) apontará não só a conveniência destas disputas, mas também a importância destas na composição da política para novos tempos: "L'un de ses derniers ouvrages, Éloge de la politique profane, se conclut une fois encore sur l'idée que la politique «n'est ni une science de l'administration, ni une technologie des institutions, mais un art des conjonctures propices et de la décision $\square$ ». Une telle définition n'a rien de spéculatif, décidément. Cette orientation a conduit Daniel Bensaïd à réexplorer aussi la question des formes institutionnelles et juridiques, de la représentation tout particulièrement et, en un mot - mot aussi galvaudé et indispensable que celui de 'communisme': celui de 'démocratie'." 
vides et qu'elles ont leur efficacité propre. Il en soulinait seulement les limites historiques" (Bensaïd, 2009, p. 56), desfechando que "l'émancipation politique [celle des droits du citoyen] est un grand progrès; ele n'est certes pas la forme ultime de l'émancipation humaine en general, mais elle est la dernière forme de l'émancipation humaine au sein de l'ordre du monde tel qu'il existe jusqu'à presente".

Em outras palavras, tomado como um "considerável avanço" (Bensaïd, 2010a, p.86), é também "o combate em favor das liberdades públicas no âmbito do Estado" considerado "importante, mas não um objetivo em si” (Bensaïd, 2010c, p.11), levando-as a uma localização particular na luta contra as opressões e o trato da estratégia e programa dos marxistas revolucionários.

Sem perder de mente que o direito, tal qual o Estado - seguindo as formulações marxianas de Guerra Civil na França (Marx, 2011) -, em um processo pós-revolucionário deverá fenecer com o comum fenecimento do antagonismo de classes (Bensaïd, 1989, p.267), pode, porquanto as marcas da sociedade do capital perdurarem, ter uma serventia de tensionador e contradições e condensador de pautas políticas transicional (Bensaïd, 2017b), como compreende desde a leitura de Evgeni Pachukanis.

Estas teorizações - tanto em sua juventude, quanto aos sabores da Comuna de 1871 - foram feitas por Marx desde uma realidade de "impasse histórico", em que "a simples expansão das liberdades públicas e a "verdadeira democracia"” - apenas formal e parlamentar - "não são suficientes" (Bensaïd, 2010c, p.15) à consecução dos interesses dos trabalhadores e trabalhadoras em luta revolucionária. Bensaï, por sua vez, encontrará paralelos da experiência marxiana no mundo que o circundava, atualizando de forma inventiva e aberta as formulações do Mouro. É pela senda trilhada por Marx que o militante-filósofo francês evidenciará a incompatibilidade da lógica sistêmica capitalista para com a salvaguarda da "proclamada universalidade dos Direitos Humanos ou do reconhecimento de uma igualdade substantiva", tensão contraditória que apenas aprofunda os efeitos da crise civilizatória que ora vivemos (Bensaïd, 2004, p.463).

Curioso notar, porém, como o tema dos Direitos Humanos exsurge de formas e intensidades distintas no curso de sua vida. Por 
exemplo, não se percebem discussões que permeiam o trato do tema quando de suas avaliações - tanto no calor do momento (Bensaïd, Weber, 1968), quanto a título de balanço posterior (Bensaïd, 2004; Bensaïd, Krivine, 1988; 2008) - acerca dos eventos de maio de 1968. Suas primeiras aproximações com o tema, ao menos em sua expressão mais explícita, passam a despontar da avaliação conjuntural da crise internacional capitalista irrompida nos anos 1973-1974, caracterizando-a como antessala da escalada neoliberal. Esta não só trouxe um processo de retração de conquistas sociais, consequência da ofensiva burguesa global frente aos meios de existência dos trabalhadores e trabalhadoras, como também encurralou a crítica marxista na academia. Em um cenário em que complexas contradições se reduziram a binarismos vazios, os Direitos Humanos acabam por assumir importante papel na defesa da ordem social capitalista contra um espantalho socialista:

Inaugurant le retournement à la baisse de l'ond longue de l'économie mondiale, la récession de 1973-1974 préluda à l'offensive libérale de Thatcher et Reagan. Le reflux des luttes sociales suscita alors de nouvelles interrogations sur la réalité et sur la vocation émancipatrice du proletáriat. La 'question sociale' était refoulée dans les coulisses de la scène universitaire et éditoriale, au profit de la philosophie politique classique. Les paradigmes de la justice et de la communication prenaient le pas sur celui de la production, la culture du consensus sur celle du conflit. Le jargon de la postmodernité avait le vent en poupe. La ligne de front entre capitalisme et socialisme, entre impérialisme et luttes de libération, s'estompait au profit du clivage idéologique entre totalitarisme et droits de l'homme. (Bensaïd, 2004, p. 422)

A redução de seu olhar ao concreto, desde a realidade francesa, remeterá a um balanço crítico acerca de sua geração de militantes. Ou seja, daquela mesma geração que irrompe vigorosamente no Maio de 1968, e que no bojo do movimento radical pouco ou nada acumulava sobre o tema dos Direitos Humanos, a ponto deste não se evidenciar nas leituras de Bensaïd sobre o período. Reconhecendo seu caráter plural e heterogêneo - tanto quanto a origem processual 
que remete a movimentos anteriores a 1968, quanto aos desdobramentos militantes nos anos subsequentes (Bensaïd, 2010b, p.10-11) -, não deixa de perceber que uma expressiva parcela destes sujeitos e sujeitas seguiu empenhado na construção de organizações revolucionárias nos anos que sequenciaram a irrupção do movimento. Todavia, a reação neoliberal ensejou inflexões profundas nas trajetórias políticas de grande parte destas pessoas, inclusive com a incorporação de parte desta militância à institucionalidade política, sobretudo no governo presidencial de François Mitterrand. Neste particular, também a defesa discursiva dos Direitos Humanos aparece como determinante na relocalização política deste corpo de ex-militantes comunistas que viviam a longa crise de direção experimentada pelo movimento. Em suas palavras:

En France, après vingt ans de règne sans partage de la droite, le mitterrandisme ouvrait les carrières aux appétits de promotion générationnelle. Ravis de pouvoir enfin faire l'ange, après avoir trop fait la bete, les déçus du maoïsme se recyclaient pour partie, sous couvert de défense des droits de l'homme et de croisade démocratique contre les périls totalitaires, dans l'anticommunisme militant. ${ }^{4}$ D'autres s'adonnèrent aux délices tempérés de la "pensée faible". Alors que nous avions grandi sous le compromis social des Trente Glorieuses, nous nous trouvions plongés brutalement dans la vague glacée de réaction libérale. (Bensaïd, 2004, p.277)

Não deixa de evidenciar, assim, como a tentativa de dissolução do comunismo em suas falsificações burocráticas - muito embora saibamos de sua irredutibilidade às experiências pós-revolucionárias burocraticamente degeneradas (Bensaïd, 2008c, p. 71-79;

4 A mesma formulação aparece, com outros complementos, no prefácio à edição inglesa de Marx, l'intempestif, traduzido como Marx for our times: "Under the impact of the neo-liberal counter-reformation, the 1980 s were years of lead for militant Marxism. In France, Mitterrandism opened up careers to the appetite for social promotion. Those disappointed in Maoism largely realigned themselves with a human rights anticommunism, delighted at the chance to be on the side of the angels after having played the fool for too long. O thers indulged in 'weak thought' and postmodern resignation. In his Confession d'un enfant du siecle, Musset evoked a sense of something vague and floating in connection with the Restoration, marking the transition between a finished past and an uncertain future. A disenchanted generation lived through the age wrapped in the mantle of egotism. In the absence of more noble enterprises and ambitions, in this 'hideous sea of action without a goal', the time was ripe for the cynicism of the victors, for trifling entertainments and minor virtues. Faced with a new reaction and restoration, are we in our turn going to be reduced to minimalism and miniaturism? Are we going to be shipwrecked on the dark sea of action without a goal?" (Bensaïd, 2002, p. xii). 
2017a, p.228-229) - passou pela afirmação discursiva dos Direitos Humanos, polarizando sua afirmação como antípodas diretos e necessários dos regimes autoritários.

Tomando a generalização estalinista como face única (ou possível!) do comunismo ou da obra Marx (Bensaïd, 2017b, p.73), e buscando a revitalização das filosofia política liberal, denunciou Bensaïd também as bases teóricas de sustentação deste movimento. Este encontrou importantes referências em Hannah Arendt (Bensaïd, 2017b, p.83) e Norberto Bobbio. Quanto ao último, menciona:

Embora lance um debate de qualidade, a proposta de Bobbio participa do processo de restauração da ordem institucional, de reabilitação da filosofia política liberal e da reconquista ideológica. Alimenta uma corrente reformista que revaloriza a 'longa marcha das instituições'. Paralelamente, favorece o impulso de uma corrente liberal reacionária, anunciada pelos chantres da nova filosofia que se dedicam a apagar a luta de classes e as resistências anti-imperialistas em benefício de uma clivagem 'humanitária' entre direitos do homem e totalitarismo ou democracia de mercado e totalitarismo até acabar, para alguns, na órbita dos neoconservadores americanos. Nessa guinada dos anos 1970, o movimento comunista "ortodoxo", na defensiva, cedeu ideologicamente sem combater, renunciando sem clareza teórica à noção de ditadura do proletariado. Não só à expressão - o que poderia justificar para evitar as confusões com o termo de um século que conheceu muitas ditaduras - mas às questões cruciais a ela ligadas, suprimidas por um risco de caneta, por abandono desenvolto, no final de um indecente strip-tease teórico, da crítica marxiana do fetichismo do direito e do Estado. (Bensaïd, 2010a, p. 82)

Ao revés do que marca a formulação teórica destes pensadores, que marcados pela existência de um suposto pecado original no pensamento de Lênin, ou mais remoto ainda, em Marx, o contrário deve ser reafirmado. É uma das construções que Bensaïd sinaliza com profundidade em Marx, o intempestivo (Bensaïd, 1999) no que se refere à Revolução Russa, e que, quanto ao teórico e prático de Trier: 
A obra de Marx é também seu combate incessante contra os privilégios, as desigualdades e o despotismo, e a favor das liberdades civis, dos direitos de organização e expressão, da liberação das mulheres e da autodeterminação dos povos oprimidos. Os que fazem de Marx o pai fundador do "totalitarismo" veem Sobre a questão judaica como o "manifesto" e o "breviário" do aprendiz de ditador. No entanto, é nesse texto que Marx salienta a contribuição indispensável das conquistas democráticas burguesas, analisando ao mesmo tempo sua relatividade e seus limites. Nesse texto, ele qualifica a "emancipação política" burguesa como um "grande progresso", "a última forma da emancipação humana nas condições atuais". O que Marx questiona é "a imperfeição da emancipação política", não para negar seu alcance, mas para abrir a perspectiva de sua "superação" num sentido que implica a conservação e a transformação qualitativa dessas liberdades. (Bensaïd, 2017b, 75)

E arremata:

Foi a burocracia stalinista, e não Marx, que decretou realizadas a unidade sem falhas do proletariado e a identidade da sociedade com o Estado, esmagou as contradições da consciência coletiva em movimento sob o imperativo da Razão de Estado e fundiu na esfera do direito público todos os ramos do direito. (Bensaïd, 2017b, p.76)

Estes "vôos líricos" - como Bensaïd convenientemente chamou a cantinela burguesa dos Direitos Humanos ao relatar anedota sobre sua primeira visita aos Estados Unidos, dada no início dos anos 1980, ainda sob o governo Jimmy Carter (Bensaïd, 2004, p. 298) - passaram a se mostrar não só mais intensos mas a cada dia mais cínicos com a escalada da "guerra ética" de afirmação capital-imperialista (Fontes, 2010). A ruptura entre meio e fins, há muito denunciado pelas e pelos marxistas revolucionários (Geras, 1978), é instrumentada para que sob a bandeira dos Direitos Humanos, as mais graves violações humanitárias venham a ser perpetradas. Sobre o tema, evidencia Bensaïd:

Selon le moralisme utilitaire de Stuart Mill, la fin du bien commun justifie moralement les moyens. De même, chez les partisans 
contemporains de la 'guerre éthique' ou 'humanitaire', la pureté des intentions (la défense des droits de l'homme, l'ingerence humanitaire...) finirait par justifier les moyens les plus douteux, et l'idéal éthique la pire des terreurs armées. Qu'est-ce qui justifie la fin? Demande au contraire Trotski. Et qui est le juge? La morale ne descend pas du ciel en planant au-dessus de sociétés déchirées par les luttes et les conflits sociaux. Le moyen ne peut être justifié que par la fin, 'mais la fin aussi a besoin de justifications'! Le vice est niché dès l'origine dans la question. En séparant la fin des moyens, la 'moraline' bourgeoise s'est fourrée dans une impasse logique. (Bensaïd, 2004, p. 348-349)

Daí tanto pela guerra, como pelas demais agências capitalistas postas em marcha no curso das últimas décadas, a discursividade dos Direitos Humanos serve de pretexto à sua efetiva negação, abrindo margens apenas à consagração do domínio da mercadoria:

Sous pretexte d'extension généralisée des droits de l'homme, les intelligneces serviles de Davos et les marchands d'illusion médiatique prétendaient hier. Encore que les dominations impériales étaient devenues solubles dans l'homogénéité marchande. Et c'est toujours le même développement, toujours aussi inégal, toujours aussi mal combine, le même système hiérarchique de force et de commandement nécessaire pour disciplines le comportement chaotique des marches. (Bensaïd, 2004, p. 464-465)

As formulações expostas revelam o grau de atenção ao tema em diversos momentos de sua trajetória, mas não externam de forma sistematizada e com mais amplo fôlego o trato da instrumentalização dos Direitos Humanos pelos vencedores da história. Atento ao tema, que remete arqueologicamente à percepção de Carl Schmitt quanto ao uso político da noção de humanidade (Bensaïd, 1999b, p. 27), aparecem apenas como indicativos importantes, que sobretudo em sua autobiografia não se fazem esconder. São em outras obras, tratando de temas particulares diversos, que podemos notar tais formulações de forma mais sólida. Daí nos parecer necessário passar pelas discussões trazidas pelo autor quanto à garantia dos Direitos Humanos desde o processo revolucionário francês do fim do século XVIII, evidenciando 
a inconclusão desta grande empreita, até as recentes agências imperialistas que sob o pavilhão do humanitarismo se colocam na afirmação de uma "guerra ética" que não esconde suas reais e fortemente econômicas fundamentações, para ser possível apreender um panorama amplo de suas impressões sobre o tema.

\section{UM ASSUNTO PARA A REVOLUÇÃO}

A primeira dimensão que pretendemos trabalhar a lida com os limites dos Direitos Humanos e sua instrumentalização circunstancial pelos vencedores da ocasião foi exposta por si exposta em Moi, la révolution (Bensaïd,1989). O livro segue forma pouquíssimo usual: sua narradora e figura principal, a Revolução, interpela François Mitterrand aos ventos da aclamação pública do Bicentenário de 1789. Trata de fatos e personagens, expondo as vísceras contraditórias dos processos políticos dados outrora e quando de sua redação, expondo as injunções e rupturas entre os dois momentos, tudo desde a referência desta velha senhora, que não mede esforços a apontar quem esteve ao seu lado e contra si. Em outras palavras:

Moi, la Révolution, c'est une manière de faire parler l'histoire, comme un fantôme sympathique, une allégorie qui sortirait de son rôle et qui saurait rendre dérisoires des retours de bâtons antirévolutionnaires aussi vieux que la Révolution elle-même. (Lacoste e Walnich, 2010, p.69)

No que se refere ao tema dos Direitos Humanos, a maior parte de suas formulações aparece no seu capítulo I, de título bastante auto-explicativo, "Mes droits inacheves". Em seu desenrolar, Bensaï evidencia, pela boca da Revolução, como a promessa por ela posta de garantia universal de Direitos Humanas é interditada no curso dos eventos inaugurados em 1789, encontrando entraves até os dias de hoje para sua efetivação. Para tanto, debruça-se particularmente sobre três manobras postas para negar direitos civis e políticos - sobretudo estes últimos - a diversos seguimentos da população: a instituição do voto censitário, a tardia e vacilante abolição da escravatura e a exclusão das 
mulheres de uma cidadania ativa, ou seja, carente de direitos políticos plenos. Nas palavras da Revolução, por Bensaïd:

Dans le moment propice, où j'ai manqué de vigilance, où j'ai laissé filer les príncipes, en me disant que je les rattraperais au tournant; dans le triple manquement aux droits de l'impropriétaire, de l'esclave, et de la femme; dans la triple contriété à mon príncipe d'universalité par le suffrage censitaire, l'exclusion des femmes et le maintien de l'esclavage. (Bensaïd, 1989, p.37)

Como se percebe, muito embora as reflexões perpassem o complexo de Direitos Humanos - não só aqueles positivados, mas muitos dos que decorreriam de uma apreensão da condição humana própria do direito natural, de idênticas disposições universalistas -, o olhar de Bensaïd, comutado na Revolução, volta-se fundamentalmente ao texto da Declaração Universal dos Direitos do Homem e do Cidadão, de 26 de agosto de 1789, em especial naquilo em que ela não guarda de universalidade.

Permeada por uma série de premissas políticas relevantíssimas à conformação de um novo arranjo societal, carregado de marcas progressivas, o texto votado pela Assembleia foi também instituidor dos principais fundamentos próprios da ordem jurídica burguesa, que então passava a se maturar rapidamente desde a realidade francesa. O reconhecimento formal da liberdade e igualdades dos sujeitos, dos direitos basilares como sendo a "liberdade, a propriedade, a segurança e a resistência à opressão", o primado da legalidade e a instituição da célula elementar da organização da politicidade burguesa no Estado soberano nacional, revelam a importância do instrumento, que transcende os interesses da classe que o instituiu - a burguesia - e impulsiona, em princípio e por princípio, a libertação universal que a Revolução anseava (Bensaïd, 1989, p.35 e 68).

É na dinâmica de redução da textualidade da Declaração ao concreto que podemos destacar os pontos a que Bensaïd se volta, e também o primeiro anúncio do uso instrumental dos Direitos Humanos a que remete. Este não aparece nos idos do século XVIII. Reside, sim, no fato do governo "socialista" de Mitterand reputar 
ao conteúdo da Declaração a existência de um "elixir consensual" (Bensaïd, 1989, p. 32) que unificaria a sociedade francesa, sendo este o grande trunfo do Bicentenário. Tal narrativa esconde não só os emaranhados que constituíram o documento político, síntese de um ajuste de compromissos complexo, intrincado e contraditório - "le premier texte de compromis parlamentaire, en somme." (Bensaïd, 1989, p.32) -, como também obnubila as profundas contradições resultantes de seus limites políticos, intentando projetar à também turbulenta conjuntura francesa de três décadas atrás um véu de inconcebível unidimensionalidade.

Bensaïd se propõe então a dizer o indizível, enfrentando esse uso instrumental de fundo: aquela Declaração, também às vésperas de completar seus duzentos anos, muito embora se avoque universal, um manto que a todos e todas cobre, como ecoava às vésperas das comemorações de 1989, na verdade deixa desguarnecida parcela significativa da população. E assim foi sua aplicação nos duzentos anos que antecederam o livro, sendo também certo que até mesmo estas pessoas descobertas não são tratadas com uniformidade: de um lado, reputa a parcela expressiva da população a destituição completa do gozo de direitos. A outras pessoas, para nos utilizarmos da formulação de Sieyés (Bensaïd, 1989, p. 41), são apenas conferidos os direitos ligados a uma cidadania passiva - marcadamente os direitos civis -, sem poder gozar, de outra banda, daqueles próprios da cidadania ativa - que contempla a plenitude dos direitos políticos.

Já o seguinte ponto de tensão contraditória reside na pedra angular da Declaração, o direito de propriedade. Este aparece como expressão político-jurídica instituidora das diferenças materiais no cerne da ordem social capitalista, fundamentalmente por seu caráter abstrato, servindo marcador distintivo entre os que podem ou não gozar plenamente dos direitos políticos, fundamentalmente o exercício do direito ao voto.

Não podemos deixar de notar que a propriedade - bem como os meandros da apropriação e da despossessão - assume um importante papel na obra de Daniel Bensaïd. Discussão abandonada pelas esquerdas francesas, em larga medida capturadas pela institucionalidade burguesa e pelo eleitoralismo (Garo, 2010, p.41), aparece em 
Bensaïd - que em muito toma a tônica de Marx na abordagem do tema- não apenas como um problema meramente jurídico, expondo a proeminência de seu caráter político (Garo, 2010, p.41-42), até em razão de que

telle question constitue l'essence même du capitalisme, matérialisant l'alliance de ses règles de droit, de son fonctionnement institutionnel, de sa violence répressive, de son art de l'exploitation toujours renforcée et, bien entendu, de ses inégalités sociales désormais croissantes. (Garo, 2010, p.43)

A problematização dessa série de elementos aparece nitidamente em seu opúsculo Les dépossédés (Bensaïd, 2007b) ${ }^{5}$. Não por outra razão Isabelle Garo (2010) evidencie como as articulações entre o trato da apropriação/despossessão e o exercício democrático se imbricam na obra do militante-filósofo francês, fato bastante nítido em seu último texto publicado em Contretemps, "Força do Comunismo" (Bensaïd, 2017a) e outros escritos do fim de sua vida (Bensaïd, 2008a).

As formulações trazidas em Moi, la révolution antecedem em muito as lançadas nas três obras acima citadas, e caminham por veredas distintas. Ligam-se, justamente, ao trato do direito à propriedade na Declaração Universal de Direitos do Homem e do Cidadão, bem como sua utilização como interditora ao gozo de direitos políticos no contexto que sequencia 1789.

De um lado, assim, alça-se à condição do mais relevante e sagrado dos direitos, construção ideológica que se aperfeiçoa no transcorrer histórico da França pós-revolucionária, bem como em outras sociedades capitalistas, mas também como primado não conferido à maior parte da população, ao menos no que se refere à propriedade privada, ou seja, a propriedade dos meios de produção.

A tomada política do tema-dentro destes registros, mas também em sua apreensão crítica - leva Daniel Bensaïd a remeter a uma miríade de fundamentos, dentre os quais o direito natural. Retomado desde Fichte com alguma simpatia (Bensaïd, 1989, p.34), o tema é

5 O livro foi publicado em português com tradução literal, "Os despossuídos", mas como se fosse uma obra de Karl Marx (2017), por razões editoriais desconhecidas. 
recepcionado de forma bastante comedida por Bensaïd. É o que se pode notar de sua crítica a Ernest Bloch, que muito embora faça adequada leitura dos Direitos Humanos, se fia "na velha trincheira do direito natural" para cozer suas formulações (Bensaïd, 2017b, p.81), ou mesmo das linhas sobre o jovem Marx, recém formado em direito e bastante impactado por seus mestres, em seus debates sobre a lei referente ao furto de lenha (Bensaïd, 2007b). Porém, é sobretudo nos potenciais usos pelos revolucionários franceses do século XVIII que centra suas ponderações, reconhecendo ter neste ambiente o jusnaturalismo se tornado objeto de "multiples et complexes controverses" (Bensaïd, 1989, p.34).

Diz a Revolução de Bensaïd que “de 89 à 93, j’ai déroulé jusqu'au bout le fil d'Ariane du droit naturel, j'en ai explore les limites. Ensuite, la courbe s'est inversée, le fil s'est remis en bobine. On rebroussait chemin. Je dis 'on', car ce n'était déjà plus moi qui menais le bal.” (Bensaïd, 1989, p.35). Não por outra razão reconheça os três pontos tangenciados neste item, marcadores da universalidade interdita dos Direitos Humanos, como derrotas do direito natural (Bensaïd, 1989, p.89), dado o grau de proeminência deste na indução política dos revolucionários franceses.

Assim, a premissa de igualdade, indutora não só da teoria jusnaturalista como constitutiva do espírito das Luzes, se expressa textualmente na Declaração, tomando contornos e sentidos bastante particulares na sua projeção prática. Tal se diz por assumir exclusivamente uma salvaguarda à igualdade formal dos sujeitos a que se destina, encontrando fissuras justamente nos elementos que poderiam levar tal condição a ser compreendida a partir das condições de existência materiais dos sujeitos de direito. As tensões entre o idealismo próprio do direito natural e o direito histórico - condicionado pelas possibilidades postas na concretude pela luta de classe - acabam por se perceber, inclusive com a reversão posterior das alterações de regime implementadas pelos revolucionários franceses:

L'égalité de 1789 concernait les droits politiques et civiques, non les droits sociaux au travail, à l'éducation, à l'existence. La Constitution concevait timidement um 'établissement general de Secours 
public', pour les enfants abandonnés, les pauvres, les infirmes, et adoptait un príncipe 'd'instruction publique commune et gratuite'. Elle contenait pourtant une entorse de taille au droit naturel. En affirmant que la royauté serait déléguée héréditairement à la race régnante, de mâle en mâle, à l'exclusion perpétuelle des femmes, elle sacrifiait le droit naturel au droit historique. Double entorse, même: ele possait un príncipe héréditaire, outrageant l'égalité de naissance, et maintenait la loi salique, excluant les femmes de la succession. (Bensaïd, 1989, p.38)

Este escalonamento na lida da igualdade, fundante dos diversos regimes políticos compatíveis à dominância capitalista, distancia as liberdades civis e políticas burguesas - reconhecedoras de igualdades formais - dos direitos sociais - consagradores de uma almejada igualdade substitutiva. Não por outra razão apareçam no âmbito das leituras tradicionais do direito como constitutivas de duas gerações ou dimensões distintas de Direitos Humanos (Comparato, 2008).

A diferenciação destes dois momentos de apreensão dos Direitos Humanos remete ao papel que as tensões de classe proporcionaram na ruptura com o trato sacralizado da propriedade (Bensaïd, 1989, p.32-33), que muito embora tenha seu questionamento posto por figuras do porte de Marat, é lido por por Bensaïd (1989, p.44-45) como defeito de fabricação da Declaração.

É, podemos dizer, na viragem da correlação de forças posta entre as classes sociais que se colocam em ofensiva na busca de seus interesses que estas "gerações" ou "dimensões" se assentam. De início, a consagração do direito de propriedade como referência ao gozo de direitos e liberdades civis, tal qual firmado na Declaração, deriva da afirmação burguesa. Sua torção política, constituidora dos Direitos Sociais, por sua vez decorre da ofensiva proletária.

Inegável que a propriedade, ontem e hoje, não se manifesta de uma mesma forma. Os graus de concentração de capital e a qualidade como a mercadoria domina nossas vidas é outra atualmente. Mas ainda assim, seja nos fins do século XVIII ou hoje, sua leitura social determina a clivagem societal em classes. Não por outra razão Bensaïd (1989, p.41) desenvolva suas formulações quanto a esta divisão como determinante no escantear de larga parcela da população 
de sua vida política:

Les classes prenaient la releve des ordres. Leurs particularités nouvelles se mettaient en travers de mes rêves universels. Tous les symptômes en étaient inscrits dans le double critère, d'imposition et de domicilation, du suffragre censitaire. Le premier renvoyait à la propriété: il fallait être 'actionnaire', pour être bon citoyen. Le second était plutôt 'sécuritaire', comme vous diriez aujourd'hui. On pense d'abord aux vagabonds, aux mendiants, aux marginaux, mais il touchait tout ela main d'oeuvre nômade, tout le petit peuple de saisonniers, de compagnons, de journaliers, d'artisans et de commerçants itinérants. (Bensaïd, 1989, p. 41)

A esta cisão, e ante estas contradições que aprofundavam a míngua da massa trabalhadora da população, defendeu o já mencionado Marat a autorização àqueles e àquelas que tudo faltava, destituir o supérfluo dos que muito têm (Bensaïd, 1989, p.42). Transmutou, pois, "a ideia harmoniosa e pacífica do direito natural em um direito absoluto e selvagem à vida", conferindo conteúdo social aos direitos políticos (Bensaïd, 1989, p.42), em uma formulação que nada tinha de idealista, mas que revelava também anseios próprios das bases sociais que serviram de força motriz à revolução francesa.

Tamanha era a radicalidade da proposta de Marat, colocando em xeque o direito de propriedade, que até a Revolução se assustou (Bensaïd, 1989, p.43)!

Estas proposições fazem despontar em Bensaïd a embrionária formulação acerca de um direito de existência - que entendemos possa ser verificado na obra de Bensaïd desde um referencial transicional, e jamais um fim em-si - contraposto ao direito de propriedade, alicerece da ordem burguesa (Bensaïd, 1989, p.44).

Muito embora apareça de forma mais maturada e desenvolvida em outras obras (Bensaïd, 1999b, 2000, 2003, 2007, 2008c), na obra do Bicentenário, porém, ressalta que este direito de existência serviria de premissa fundante à reivindicação e ao gozo de todos os demais direitos (Bensaïd, 1989, p.268).

Bensaïd chega a indagar os motivos de não se decretar um estado de urgência social, que proporcione que o direito de existência 
se sobreponha ao direito de propriedade (Bensaïd, 1999b, p.31, 2003, p.290). A resposta à sua indagação é simples, porém: sem a investidura dos trabalhadores e trabalhadoras no poder, pelo caminho qual seja, sobrepujar as pedras basilares da ordem social do capital será impossível.

Podemos dizer que nem mesmo as poucas torções políticas que levam a lógica privatística do direito a conformar os Direitos Sociais (Seferian 2019a, p. 388-389, Seferian, 2019b, p. 4) no século XVIII se sustentariam. A crescente dissolução dos laços de fraternidade - que em muito se diferenciam da piedosa e inócua caridade cristã, "ostentatória e interessada", em que a oferta se coloca espetacularmente como uma entrega a Deus (Bensaïd, 1989, p.45) -, esta também constitutiva da bandeira revolucionária, estaria no cerne da resistência posta ao direito de existência, inclusive nas moderadas proposições de Robespierre de um direito ao trabalho e à assistência como sendo direitos naturais (Bensaïd, 1989, p.46).

A prevalência da propriedade na abordagem dos Direitos Humanos eclipsa, deste modo, a afirmação universal de Direitos Humanos em uma sociedade em que a propriedade exclusiva da força-de-trabalho é a sina de quase a integralidade da população, ou seja, daquelas e daqueles que não conformam estruturalmente as franzinas classes proprietárias.

O desdobramento do texto nos faz perceber que a leitura do militante-filósofo não escalona ou hierarquiza as dimensões da opressão marcadas pela sociedade moderna. Muito embora a dimensão de classe seja indispensável para a compreensão dos processos sociais e políticos, não se esgota nesta como determinação única. Seu olhar para a condição dos proprietários criollos e negras e negros escravizados do Haiti, por exemplo, revela como que as opressões de classe e raça se entrecruzam e se qualificam dialeticamente.

Podemos então destacar um terceiro foco do uso instrumental dos Direitos Humanos pelas classes dominantes quando Bensaïd volta seus olhos para a realidade colonial e investe contra a chaga da escravidão. Esta que por tantos anos, mesmo após a Revolução Francesa, seguiu perdurando nas colônias e metrópole, fazendo aflorar uma série contradições na lida com os Direitos Humanos. 
É de se destacar, antes de tratar de outros meandros sobre o assunto, que as formulações de Bensaïd não resultam de obra de seu gênio, não são idealistas, mas sim derivam da materialidade revolucionária posta no Haiti. Não por outra razão afirme que "tout part de Saint-Domingue" (Bensaïd, 1989, p.52).

O contexto que resulta do 22 de outubro de 1789, revisitando a proposição originalmente universalista que se pretendia conferir à Declaração, erige a distinção de cidadãos ativos e passivos e faz recair a perda de direitos políticos não só aos escravos, mas também aos mulatos do Haiti (Bensaïd, 1989, p.54). Mesmo a proclamação da República pela Convenção nada fez pelas pessoas escravizadas. A inação própria da tardia a movimentação institucional, aliada com o reverberar dos ecos da Revolução pelo Caribe, leva à irrupção de uma revolta negra em agosto de 1791, esta que institui novos líderes populares, vindo das cozinhas, estábulos e plantações (Bensaïd, 1989, p.56). O anseio dos insurretos, inclusive, era de ampliar a participação política dos viventes na ilha, criando uma paralela institucionalidade representativa. Dois anos mais tarde, em agosto de 1793, antes que na metrópole, o processo continuado de insurreição ousa abolir por si própria a escravidão (Bensaïd, 1989, p.57). A Convenção, pressionada pelos eventos, foi apenas em 4 de fevereiro de 1794 abolir a escravidão, em festejada e hipócrita votação, "comme une apothéose des Droits de l'homme" (Bensaïd, 1989, p.58) assaz tardia. Nas palavras de Bensaïd:

Une conclusion désabusée, à contre-temps plutôt qu'une victoire, un soupir plutôt qu'un cri de joie. Résumant plus de quatre ans de tergiversations, cet 'enfin' jetait sur la Déclaration des Droits une ombre rétroactive. (Bensaïd, 1989, p.58)

Ainda, em outras palavras:

Bref, l'abolition de l'esclavage n'était plus une victoire propulsive et cumulative. C'était déjà une victoire posthume et declinante, qui fait à peine illusion. Un sobresaut à contretemps. Le rattrapage d'um inavouable compromis. Une révolution à retardement dans la révolution. (Bensaïd, 1989, p.61) 
Parte da intransigente postura metropolitana, que escancara as contradições capitalistas e os limites de suas conformações jurídicas, parte justamente da lida com as colônias desde uma lógica de possessão nitidamente proprietária, que marca a tônica estrutural da ordem burguesa. Demover os artífices da Declaração e das primeiras constituições francesas desta marca de sacralidade, já exposta alhures, tanto em sua lida com as colônias como no trato das pessoas escravizadas, sobre as quais o signo da mercadoria e da propriedade também recaiam, reclamava um embate classista intenso. Fato este que torna a abolição da escravatura, como comentam Lacoste e Walnich ao tratar de Bensaïd (2010, p.72) uma demanda "honesta e difícil" (Lacoste e Walnich, 2010, p.72), e que por tais qualidades deve também ser reconhecida.

Ocorre que da mesma sorte que os conscientes retrocessos postos quanto ao sufrágio censitário - e depois, em temas que Bensaïd não aprofunda neste ou noutros textos, tratando superficialmente (Bensaïd, 1999b, p.35) mas que tão bem são trabalhados por Marx em Luta de classes na França (2012) -, também uma derrota futura, um retrocesso, poderia retumbar a conquista da abolição. Diz isso até em razão de que os limites à anseada universalidade dos Direitos Humanos não derivarem de simples "pecados” da Declaração, resultantes de "precipitação" ou "incompletude" de seu texto(Bensaïd, 1989, p.47). São marcas estruturais próprios da lógica sistêmica capitalista, que tornam sua efetivação impossível sob a dominância mercantil, e que por isso ideologicamente busca escamotear as inflexões do processo de luta de classe sob a tônica do Progresso maiúsculo, linear e inarredável (Bensaïd, 1989, p.49).

Tanto é verdade que em suas formulações, aparece a inexistência de uma crença ingênua pelos oprimidos e oprimidas no Progresso maiúsculo, que não comporta retrocessos em sua linearidade histórica:

Les nègres savaient que l'histoire est parfois réversible, e qu'um décret, si tardivement adopté par une lointaine République, relevait de la pression des événments plutôt que de la difélité à des príncipes trop longtemps contredits....La metrópole blance, em proie 
aux convulsions et aux crises gouvernementales, pourrait reprendre as parole. Il faudrait alors défendre cet affranchissement avec les dents. (Bensaïd, 1989, p.61)

A percepção da possibilidade - e efetivação! - de retrocessos chega ao ponto da Revolução figurada por Bensaïd afirmar que a lei de 20 de maio de 1802, que reinstitui a escravidão na França e territórios de ultramar, ser uma "irrefutável prova" de sua derrota. (Bensaïd, 1989, p.64).

Mas o complexo processo haitiano não nos possibilita perceber de modo homogêneo as percepções acerca da Revolução Francesa. Caso emblemático é o de Toussaint Louverture, que se viu também envolvido pelo peso ideológico das Luzes. Muito embora tenha no curso da vida mudado sua postura conciliatória para assumir uma posição política de maior intransigência (Bensaïd, 1989, p.57), morreu fiel às bandeiras revolucionárias francesas e em alguma medida crente no devir libertador do processo burguês, sem ousar declarar a independência haitiana (Bensaïd, 1989, p.62), que veio a se dar apenas em $1^{\circ}$ de janeiro de 1804 , pouco depois de sua morte, em 7 de abril do ano anterior.

Aqui reside uma importante dimensão da captura ideológica posta também aos lutadores e lutadoras daqueles e destes tempos. É inegável o conteúdo progressivo e revolucionário inscrito não só no corpo teórico Iluminista como nas chaves constitutivas da Declaração Universal dos Direitos do Homem e do Cidadão. Não reproduzimos aqui as formulações pouco matizadas de Karl Marx e Friedrich Engels no Manifesto Comunista (2010), que futuramente são revistas ao perceberem que as marcas de progresso capitalistas carregam consigo ainda mais impactantes traços de retrocesso. Nossa percepção, tais quais as de Bensaïd, reconhecem as conquistas no plano dos Direitos Humanos como importantíssimas, ainda que limitadas. E isto sobretudo em uma conjuntura política, econômica e social ainda mais aterradora que a contemporânea, como era experimentada no Haiti do século XVIII. Estamos aqui a falar da legítima adesão de uma liderança revolucionária - a maior delas! -, em um processo insurrecional de vanguarda - o primeiro deles! - de largas proporções - o maior deles! -, a um chamado de libertação 
universal, em princípio indistinto, mas que encontra os percalços da história em sua efetivação.

Também histórica é a constatação sobre as potências e limites dos Direitos Humaos na lida dos processos revolucionários francês e haitiano, haja vista que conteve as ofensivas insurrecionais, mas dialeticamente também as impulsionou.

Não é, pois, a abordagem dos Direitos Humanos passível de soluções simplistas, sejam proclamadoras de uma pura captura e anestesia das lutas revolucionárias, seja tomando-os como um deus ex machina solucionador de todas as mazelas sociais. Como todo construto social, também os Direitos Humanos são permeados de contradições, servindo de fermento e contenção à luta revolucionária. Reducionismos e simplismos para com a leitura da juridicidade, como os postos por Bernard Edelman (2016) ao versar do Direito do Trabalho - repleto de ilações não fundamentadas, fraturas para com a dialética e "pontos finais" irrefletidos - não servem à complexa riqueza da lida convergente entre direito e política.

A complexidade da dinâmica não se resume aos pontos tratados. Expressa-se ainda no fato da dinâmica de libertação da negritude haitiana ter se desdobrado em uma guerra. E não uma guerra qualquer: aponta Bensaïd (1989, p.63) que "ce fut la première guerre coloniale conduite par une nation républicaine moderne”. Prenúncio das guerras coloniais vindouras (Bensaïd, 1989, p.65), assumiu um caráter de guerra de extermínio (Bensaïd, 1989, p. 66, 134 e 208), que no intrincado combinar de modalidades bélicas, também viu manifestar uma relevante dimensão ideológica marcada pela bandeira tricolor.

Mas antes de adentrar nos aspectos concernentes à guerra e a narrativa dos Direitos Humanos neste contexto, tratemos de uma quarta e última dimensão de seu uso instrumental também tangenciada por Bensaïd ao olhar para a luta histórica na França da virada dos séculos XVIII para o XIX.

A origem comum que atravessa a lida de pessoas pobres, escravizadas, colonizadas e mulheres é tal que sintomaticamente, no bojo das tensões inscritas na mais que bicentenária revolução, a percepção convergente de esforços para consagração das ânsias 
de uma universalidade não apenas formal, mas renovada e substantiva, posta a todos e todas, sem distinções, abria horizontes de sensibilidade interseccionados. É o caso, por exemplo, de Olympe de Gouges, célebre pela elaboração da Declaração dos Direitos da Mulher e da Cidadã, que escreveu uma peça - proibida de encenar chamada L'esclavage des nègres, em que tratava não só da dimensão de opressão particular vivenciada pelas pessoas escravizadas mas a ligava também à dimensão de opressão de gênero vivenciada pelas mulheres (Bensaïd, 1989, p.55). Deste modo, tal qual exposto por Angela Davis (2016) desde a realidade do outro lado do Atlântico, as lutas por direitos políticos de mulheres e pessoas escravizadas convergem por efeitos estruturais - não estando, claro, isentas de tensões e contradições -, recaindo em reivindicações pontuais comuns ante a direitos interditados e na percepção geral da realidade social:

\begin{abstract}
Des brochures dénonçaient les états prétendus généraux...Un procès-verbal de l'ordre le plus nombreux du royaume réclamait le droit au divorce, le libre choix des conjoints, et l'abolition de l'usage de la dot. Une pétition des femmes du Tiers état au roi et um cahier de doléances et réclamations des femmes exigeaient une représentation des femmes aux états généraux, le droit à l'emploi, des écoles gratuites...Ils établissaient um parallèle entre notre émancipation et l'affranchissement des nègres. (Bensaïd, 1989, p.73)
\end{abstract}

Deste modo, por mais que se prenuncie como uma promessa de iguais direitos a todos e todas, também quanto ao particular trato de gênero a Declaração acaba expressando na prática a negação de tal aspiração (Bensaïd, 1989, p.73). Esta terceira grande falha, até hoje incompletamente reparada, não nos impede verificar que alguns direitos tenham sido conferidos às mulheres nos anos subsequentes à revolução - como é o caso do divórcio -, sem todavia que os direitos políticos lhes fossem conferidos (Bensaïd, 1989, p.77 e 78).

Em um interessante jogo discursivo, Bensaïd ridiculariza a tônica machista que reduz a emancipação feminina do jugo opressor à prática revolucionária exclusivamente por ela - a Revolução, mulher - estar presente no processo. Enfrenta uma forte tônica 
que contaminou o campo da militância marxista e do restante da esquerda que projetava na revolução socialista a solução de todos os males. Bastaria a viragem econômica e/ou política para que uma série de outras marcas de opressão fossem superadas. A experiência histórica, nas mais diversas realidades sociais - Rússia, Alemanha, China, Cuba, Vietnã, Nicarágua e outras - mostraram o contrário, e nada foi distinto no contexto da Revolução Francesa. Nas palavras da então bicentenária senhora, "mais je ne tolérerai plus que ma notoriété individuelle serve de prétext à 'effacement collectif de mon sexe" (Bensaïd, 1989, p. 70). E complementa, novamente expondo as tensões entre a universalidade das pretensões revolucionárias e a expressão daqueles (homens) que arrogavam para si "o privilégio exorbitante de serem mais humanos do que os outros":

"Certains, jusque dans le Tiers, s'arrogeaient le privilège exorbitant d'être plus humains que d'autres. Les males s'adjugeaient le monopole du droit naturel. Je me découvrais, avec effarement, singulière dans mon universalité proclamée.” (Bensaïd, 1989, p.73)

Ao também trazer pra si o "privilégio" do fazer político, inclusive abafando as sublevações femininas, implicariam mais do que qualquer outra coisa a conformação de uma revolução sem revolução (Bensaïd, 1989, p.83). Parte expressiva desta neutralização política das mulheres se deu pela reclusão à esfera doméstica, aprofundando as marcas da divisão sexual do trabalho - ancestral, certamente em contornos opressivos desde a institucionalidade burguesa. Nas palavras e Bensaïd (1989, p.82), passaram a viver "les femmes en quarantaine, déportées, internées, just le temps de la Révolution... Privées de révolution...”.

Deste modo, fundamental compreender que o isolamento doméstico das mulheres não é uma exclusividade capitalista, mas há muito serve de arma eficiente para neutralização política de mais da metade da população humana. É justamente no momento em que, estruturalmente, o isolamento doméstico das mulheres se coloca insustentável, reclamando que ao menos para fins de exploração de sua força de trabalho estas passem a gozar de uma vida pública- 
sem deixar as incumbências relativas ao trabalho reprodutivo, claro -, como aqueles motivados pelas primeiras guerras modernas, que se verificam as primeiras articulações de solidariedade e luta feministas modernas (Bensaïd, 1989, p.78). Rompido, pois, o claustro doméstico, a abertura da política se colocava em marcha, inclusive proporcionando inflexões no perfil militante, outrora reservado a uma dimensão intelectual e teórica, para que passasse a assumir uma proeminência prática (Bensaïd, 1989, p.79).

Mesmo antes disso, Bensaïd (1989, p.70) não deixa de destacar a participação de mulheres nas lutas efetivas para a consagração dos saldos da revolução, diferenciando aqueles apenas formais, textuais - como o da Declaração, redigidos por homens - e os efetivos passos que em 14 de julho e 6 de outubro de 1789 estiveram as mulheres incorporando. Mas é ante esse conjunto de contradições próprias de um reconhecimento quando muito formal, que não se expressa na materialidade, ou da mesma carência dos direitos legal e constitucionalmente conferidos, que a imposição da cidadania e de outras "magras conquistas" das mulheres se fez necessária (Bensaïd, 1989, p.79 e 83), demonstrando inclusive que a política não se resume à raias estatais (Bensaïd, 1999b, p.25).

A complexa e dialética ligação entre a formalização de direitos e sua efetivação faz despontar curiosa percepção quanto as já expostas contradições e limites colocados na luta por direitos, aparecendo em Bensaïd que senão etapas, os momentos de um processo político complexo projetam na formalização um marco importante, ainda que da mesma sorte insuficiente, na disputa política:

"J'entrevoyais même les pièges de l'égalité formelle, civique et politique. Certes, il fallait commencer par lá. Mais quando biens même nous l'obtiendrions, il resterait les oppressions vicieuses, les inégalités sournoises, dans la famille et le travail.” (Bensaïd, 1989, p. 73)

Bensaïd ilustra ainda algumas de suas reflexões sobre opressão de gênero exemplarmente pautado desde a prática de duas mulheres francesas, Joana D’Arc e Olympe de Gouges. Se quanto a Joana D'Arc, a quem dedicará dois anos depois um livro (Bensaïd, 
1991), não deixa de perceber que foi a subversão ao seu papel social marcado pelo gênero que a fez ser condenada e morta - já que "formellement, juridiquement, téologiquement, elle fut condamnée pour avoir repris l'habit d'homme, après l'abjuration du 24 mai 1431" (Bensaïd, 1989, p. 85) -, é tratando da já mencionada Olympe de Gouges que o tema ligado aos Direitos Humanos, em especial à Declaração, aparece com destaque.

O principal ponto de incisão posto por Olympe de Gouges foi justamente na naturalização - que de descuidada não teve nada, estando muito implicada - das ambiguidades gramaticais entre o genérico e o masculino (Bensaïd, 1989, p.73), que em verdade revelavam a ação política de uma metade da humanidade a excluir a outra do fazer político (Bensaïd, 1989, p.75).

A reiterada exclusão das mulheres do conjunto de pessoas aptas a votar, confirmada pela Constituinte, enfurece a dramaturga que, ante o circulo vicioso de interdições políticas - já que mulheres não poderiam eleger mulheres já que não poderiam votar, e sem eleger mulheres seus interesses não seriam alcançados (Bensaïd, 1989, p.76-77) - , decide cunhar sua famosa Declaração dos Direitos da Mulher e da Cidadã.

A exclusão do termo "Universal" na declaração não era também acidental, mas não exclui também a tensão posta a se conferir a universalidade anseada em discurso pela Declaração criticada e, sobretudo, pela Revolução. Incide o texto em pontos da materialidade gritante, mas também alcançando aspectos formais, como na ousada sinalização de que a Constiuição seria nula em razão da maioria das pessoas que compõem a nação não terem participação de sua elaboração (Bensaïd, 1989, p.77).

Olympe de Gouges, em suas formulações e tensões, não se vê apartada da defesa do direito natural. Neste caldo social, porém, percebe-se que a abordagem daquele importante indutor dos Direitos Humanos se transmuta na busca não mais de um marco de unidade universal entre seres humanos, mas um elemento que, restritivamente, aponta ao reconhecimento de diferenças (Bensaïd, 1989, p.89). Bensaïd não deixa de perceber, porém, que desta dimensão potente do reconhecimento do particular ante o todo jamais homo- 
gêneo, a redução ao identitarismo acabou por se cristalizar enquanto um possível desdobramento (Bensaïd, 2008c, p.35-56), que por certo não alcança só o movimento de mulheres mas também alcança outros tantos processos de luta por libertação em nossos tempos.

Diante destas três fraturas nos anseios universalistas da Declaração - que revelam a instrumentalização pelas classes proprietárias e setores opressores da sociedade do discurso dos Direitos Humanos -, Bensaïd pôde trazer algumas afirmações de caráter geral, dentre as quais a mais emblemática remete ao inacabamento da Revolução.

Expresso sintomaticamente na incapacidade estrutural da revolução burguesa consagrar a condição de igualdade substantiva, social e política de todas e todos, este caráter de incompletude da Revolução remeterá à sua instância de permanência, de um lado, e de outro ao caráter deliberado posto pela apologética burguesa em conformar uma sociedade desigual e marcada pela exploração e opressão.

É por este motivo que afirma que "la Déclaration des Droits n'était pas un brouillon inachevé et perfectible, mais un mensonge délibéré, une escroquerie morale et politique, passible de poursuites pour publicite mensongère" (Bensaïd, 1989,p. 94). Seus termos legais, guiados pela Revolução, seguem plenamente abertos (Bensaïd, 1989, p.91) não só ao fazer histórico, como também à sua efetiva consecução. Aparece a Revolução como refratária a qualquer satisfação ou contentamento parcial (Bensaïd, 1989, p.33), apontando a Declaração como um programa que carimba seu caráter de inacabamento (Bensaïd, 1989, p.268). Dai seu já mencionado caráter incompletude permanente leva-la a dizer:

"Moi, je n'ai jamais termine, je ne suis jamais au bout de mes peines, de mes joies et de mes droits (...).

Vous voulez me terminer. Je veux me continuer.

Volonté contre volonté. Stratégie contre stratégie." (Bensaïd, 1989, p. 91 e 238) 
Não só desta assimilação da Declaração como um programa inacabado, mas também do conjunto das demais formulações trazidas sobre o tema, é que podemos perceber um apego às perspectivas universalistas por Bensaïd. Longe daquelas propugnadas e conformadas em 1789, por óbvio. Afirmações no sentido de que "a recusa do escravismo ou da opressão das mulheres não é mera questão de clima, gosto, usos e costumes" e que "as liberdades cívicas, religiosas e individuais não são menos importantes em Teerã que em Londres ou Paris" (Bensaïd, 2013, p. 37) não deixam dúvida quanto a isso. A universalidade alternativa que defende Bensaïd não fecha aos olhos à negação do que pode e deve ser universalmente tratado - quanto menos utiliza da contraditória perspectiva de defesa de valores para negá-los -, e combina harmonicamente o particular desde o reconhecimento da importância do distinto e plural. Ou seja, esta universalidade nova "n'est pas de l'ordre de la proclamation (d'une universalité déjà existente, déjà donnée), mais de l'ordre du devenir, d'um 'devenir humain' ou d'um 'devenir-universel' em construction." $(1999 b, 30)$

Tudo isso, combinado aos elementos de concepção acima lançados, nos leva a perceber uma apreensão história dos Direitos Humanos - e não ligada às raízes de um direito natural, ao qual o autor sempre foi crítico -, sinalizando que mesmo os passos conferidos na institucionalidade burguesa (no caso, então em formação) acabam por se consagrar apenas como fruto de lutas classistas. Trabalhadoras e trabalhadores despossuídos, negras e negros escravizados, mulheres de todas as classes, foram artífices dos primeiros lineamentos dos Direitos Humanos, em larga medida colocados no campo dos direitos e liberdades civis, e apenas conseguiram - quando conseguiram! - promover inflexões aos limitados desenhos originais de sua textualidade por meio de embates viscerais, que devem ser retomados inclusive para que os desdobramentos reclamados pela Revolução - jamais saciada com os tímidos avanços encampados pela burguesia - possam ser plenamente efetivados.

Afinal, não deixa de perceber que "entre a luta social e a luta política" - talvez distintiva para a consecução de direitos e liberdades civis, de um lado, e dos Direitos Sociais, de outro -, "não há 
nem Muralha da China nem separação absoluta. A política surge e inventa-se no social, nas resistências à opressão, no enunciado de novos direitos que transformam as vítimas em sujeitos ativos" (Bensaïd, 2008c, p.31), se nunca deixar de estar atenta à contraditória condição existente entre o direito positivo e a política concreta (Bensaïd, 1999b, p.30), que deve se colocar em nosso horizonte de superação.

\section{4. "GUERRA ÉTICA" E A VIOLAÇÃO "HUMANITÁRIA" DE DIREITOS HUMANOS}

Todas as reflexões trazidas em Moi, la révolution foram cunhadas antes da queda do muro de Berlin - o lançamento do livro se deu em junho de 1989, meses antes dos eventos de 9 de novembro daquele ano -, agudização de processo que impacta de forma avassaladora a conjuntura global e, como não, também o pensamento de Bensaïd, posto sempre a reboque de pensar nosso mundo com ânsias transformadoras desde suas dimensões concretas.

São estes novos fatos que chamarão a atenção do militante-filósofo para, sob outro enfoque, anos depois, usar distintas cores para ilustrar o uso instrumental dos Diretos Humanos, não mais se centrando apenas nos véus ideológicos de uma universalidade humana mitigada, tal qual verificou na realidade francesa pós-revolucionária.

Os grandes dilemas conjunturais que irrompem no início dos anos 1990 - sobretudo com a guerra dos Balcãs e as intervenções militares "humanitárias" realizadas tanto na região como em outros rincões do planeta -, aliados às perspectivas triunfantes do "fim da história", levam Bensaïd a propor inventivas reflexões sobre o tema, aprofundando elaborações prenunciadas em momentos anteriores de sua vida e dando corpo a novas problemáticas.

A primeira destas percepções remete ao discurso em defesa dos Direitos Humanos explicitamente posto pelos agentes do imperialismo para condução de incursões militares, a legitimar, ao revés, graves violações a tais garantias. A já mencionada guerra dos Balcãs serve de tremendo laboratório para esta inversão política, que ve- 
remos se repetir com a escalada de violência imperialista posta no pós-11 de setembro de 2001 e outros conflitos, sobretudo no Oriente Médio e na Ásia central. O momento em que este artigo é concluído, no início de 2020, esta tônica se fortalece, passando o Irã a ser palco das tensões postas pela afirmação da discursividade imperialista dos Direitos Humanos.

Assumindo como findo o "breve século XX", como entendeu Hobsbawn (1995), Bensaïd reconhece a incursão da OTAN nos Balcãs como "la première guerre du XXIe siècle: une guerre désintéressée pour les valeurs. On a célébré l'avénement de 'la guerre éthique' (Tony Blair), 'exclusivement humaitaire' (Václav Havel), ou encore, la naissance de la 'souveraineté humanitaire' (Daniel Cohn-Bendit)"(Bensaïd, 1999a,p.13).

Muito embora pareça ser a terminologia cunhada por Blair, Bensaïd frisa não ter sido o líder Trabalhista o primeiro a usar expressão de "guerra ética", mas sim Winston Churchill. Este, no contexto da Guerra Fria, propugnou que a luta pelo direito e a proteção da liberdade em pequenos países legitimaria a Inglaterra para agir como autoproclamada mandatária em defesa da Civilização contra a barbárie, em um amálgama de elementos jurídicos e éticos (Bensaï, 1999a,p.162).

Não é de se estranhar que as formulações de Churchill foram quase que literalmente ecoadas no período por figuras investidas de grande poder. Por exemplo, Jean-Maria Colombani - editor chefe do Le Monde - arrogará a Europa à condição de mandatária da humanidade (Bensaïd, 1999a, p.68). Também "Lionel Jospin l'a dit tout net: c'est um 'combat pour la civilisation'", querendo fazer crer a possibilidade de uma cisão absoluta entre civilização e barbárie, sem considerar também a pluralidade de concepções a que as duas categorias podem comportar (Bensaïd, 1999a,p.69).

Estas simplificações maniqueístas, como propugnadas por Colombani e Jospin, mas também por Tony Blair e Bernard-Henri Lévy (1999a, p.54), firmam por exemplo raízes para a agenda Bush, e posteriormente Obama e Trump, na lida com o terrorismo, de que ou se está ao lado dos interesses estadunidenses, ou se é o inimigo. Se de alguma maneira até o término da Guerra Fria, marcado pelo 
débâcle do bloco soviético, o grande inimigo da ordem se figurava no comunista, transmutou-se atualmente no terrorista. Nas palavras de Bensaïd e Claude Corman:

Le terrorisme devient le masque de toutes les menaces et de toutes les inquiétudes. Un gros mot, un gros concept, si gros qu'il écrase la politique et l'esprit critique. La terreur ne fait pas bon ménage avec l'exercice de la raison. Le terrorisme a une histoire. Le terme aussi. Dès les années quatre-vingt, il est devenu un mot fétiche du vocabulaire américain. Il y aurait beaucoup à dire sur la manière dont il a remplacé, dans le partage manichéen du bien et du mal, le communisme. Sa menace imprécise, déterritorialisée, permet de justifier un exercice « antiterroriste » de la violence d'État où la guerre disparaît pour se muer en simple descente de police internationale, ou le droit se dissout dans la morale, où l'humanitaire se confond avec le militaire. (Bensaïd, Corman, 2002)

Mesmo na realidade brasileira, em que o saudosismo da ditadura empresarial-militar sustenta a paranoia anticomunista de Bolsonaro, o intento de neutralização de organizações de esquerda passa pela conformação híbrida, sobretudo pela perspectiva de criminalização de lutadoras e lutadores sociais (O Globo, 2018).

Contra o "terrorismo" - radical islâmico, socialista revolucionário ou de extrema direita, a revelar uma vez mais a simplificação reducionista na utilização ideológica dos Direitos Humanos -, reclama-se uma Cruzada em defesa dos Direitos Humanos pelas agências do capital. E por Cruzada entendamos "une guerre à visée religieuse ou idéologique contre l'infidèle (la barbarie), même si l'intérêt le plus trivial n'em est jamais absent (ainsi que le comportement prédateur des croisés l'illustra en son temps)" (Bensaïd, 1999a,p.162).

Passa a instalar nada menos que uma Cruzada, ou seja, "une guerre à visée religieuse ou idéologique contre l'infidèle (la barbarie), même si l'intérêt le plus trivial n'em est jamais absent (ainsi que le comportement prédateur des croisés l'illustra en son temps)" (Bensaïd, 1999a,p.162). Esta 
"lutte contre le « terrorisme » ne connaît plus de résistances et de légitimes défenses. Elle renforce le droit des forts et met dans le même sac les attentats criminels du 11-Septembre et la résistance légitime de l'Intifada. À qui profitent cette dépolitisation et cette déshistorisation des conflits ? La lutte antiterroriste fonctionne alors comme l'envers musclé de l'humanitaire. (Bensaïd, Corman, 2002)

O respaldo teórico destas formulações é uma vez mais explicado por Bensaïd com o revolvimento das bases da filosofia política liberal. Aponta a repercussão do pensamento de Norberto Bobbio, fundamentalmente desde os fins dos anos 1960, como legitimadora de uma discursividade dos Direitos Humanos supostamente amparada em um consenso geral. Em seu pensamento, seria a Declaração Universal dos Direitos Humanos de 1948 expressão pactuada desta unanimidade (Bensaïd, 1999a, p. 164). Este discurso, que como já mencionado serviu de falsa e binária polarização entre Direitos Humanos e regimes totalitários, teve como um de seus intentos diluir o comunismo nas expressões falseadas e burocraticamente degeneradas.

Uma vez mais apelando à crítica da textualidade com pretensões objetivas, Bensaïd denuncia o caráter mistificador e voltado aos interesses das classes dominantes expresso na Declaração de 1948 , percebendo em sua crítica a perigosa abertura posta na indeterminação categorial para o trato tanto do conceito de humanidade, como também da qualidade e substância dos Direitos Humanos (Bensaïd, 1999b, p.30-31).

Como não poderia deixar de ser, a questão posta quanto ao uso instrumental dos Direitos Humanos perpassa uma infindável conformação de sentidos. Estes são melhor delineados com o impulso posto às dualidades binárias próprias de tal embate, sobretudo quando as escolhas se reduzem ao "ou nós, ou eles". Daí Bensaïd (1999a, p.43) afirmar ser a guerra, nesta quadratura, uma "reducionista máquina de simplificar".

Não só quanto às palavras "civilização" e "barbárie" a máxima quanto a disputa de sentidos aparece na obra de Bensaïd ao tratar dos Direitos Humanos. Talvez a mais emblemática das problematizações perpasse justamente a categoria Humanidade, sobretudo em 
sua acepção maiúscula. Consciente da relatividade sócio-histórica da categoria - até em razão que "l'humanité n'est pas pour l'heure, immédiatement, une catégorie politique déterminée (les vainqueurs d'hier sont-ils si assurés de leur humanité?)" (Bensaïd, 1999b, p. 29) -, percebe residir aí a forma contemporânea dominante para o uso instrumental dos Direitos Humanos em uma nova conjuntura. Em suas palavras:

"Houve um tempo em que uns afirmavam representar a justiça em nome uma História com $\mathrm{H}$ maiúsculo. Hoje, outros (às vezes, os mesmos) afirmam administrá-la em nome da Humanidade com $\mathrm{H}$ maiúsculo. De onde lhes viria o direito de falar e julgar em nome dela? A humanidade não é uma substância da qual se possa apropriar, mas um futuro, uma construção, um processo de humanização ${ }^{6}$. Ela se desenvolve através do direito, dos costumes, das instituições por meio de um lento trabalho de unificação das multiplicidades humanas. Até que isso aconteça, invocar uma legitimidade humanitária às vezes serve de máscara para os interesses da dominação imperial" (Bensaïd, 2008c, p.61)

Deste modo, é certo que muito embora a autoproclamação imperialista - no caso a que Bensaïd se volta, o da incursão da OTAN nos Balcãs -, “dans le monde réel, ce n'est pas l'Humanité majuscule qui intervient et agit. Elle prête seulement son masque avenant à des acteurs plus concrets et plus patibulaires", sendo seus interesses os mais mesquinhos e imediatos de natureza econômicos (Bensaïd, 1999a, p.107).

O interesse da ofensiva da OTAN, pois, era indubitavelmente capitalista. Esta nova ordem mundial que então se forjara era a da hegemonia do capital, com pouquíssimas forças a ela contrapostas. Não por outro motivo as agências internacionais se colocavam a forjar "une déclaration des droits des investisseurs à disposes des peuples. La logique de ce nouvel ordre marchand est globale. Il a son idéologie humanitaire. Il veut as gendarmerie sans fronteires." (Bensaïd, 1999a,p.81).

6 Em Contes et legendes de la guerre éthique, Bensaïd incorpora redação parecida à ora cita$\mathrm{da}$, incluindo que o processo não seria apenas de humanização, mas també de universalização (Bensaïd, 1999a , p. 107). 
Esta "guerra ética" concerne assim na simples utilização discursiva dos Direitos Humanos para consagração de interesses imperialistas, apostando em binarismos simplistas e criação de inimigos? Cremos que não só. $\mathrm{O}$ reducionismo da lida com o direito à esfera do individuo - a mais reduzida das minorias, tal qual propugna Alain Madelin (Bensaïd, 1999a, p.73-74) -, o enfrentamento aos primados do direito positivo e o apego ao alicerçamento do direito não no poder, mas na moral (1999a, p. 75-76) trazem uma série de novas determinações para pensar os Direitos Humanos, subvertendo as balizas de pretensões radicais e universalistas nas quais são concebidos.

O imperialismo, deste modo, apenas altera qual é a chave determinante na indução de suas políticas ideológicos, e os repertórios de fratura e dominação que utiliza. Por exemplo, "à l'époque de l'impérialisme colonial, la domination s'impose aux populations étrangères à l'aide de deux grands moyens: la race em tant que príncipe du corps politique et la bureaucratie comme organisation du pouvoir." (1999a, p.133). Ocorre que "dans un monde oú les lignes de fracture s'enchevêtrent, oú les critères traditionnels sont frappés d'incertitude, la controverse sur la guerre juste exprime encore le souci de definir des limites que la technique et l'idéologie tendente sans cesse à gommer" (Bensaïd, 1999a, p.161).

A proeminência de aspectos de ordem ética passa a suplantar as regras positivadas, trazendo inflexões tanto na apreensão dos Direitos Humanos de modo geral, como na conformação do direito internacional (Bensaïd, 1999a, p.165). Deste modo, "Les droits de l'homme s'inscrevent solvente dans ce clair-obscur entre le droit positif et l'exigence éthique. L'hésitation constante entre l'énonce d'um droit (juridique) et d'um devoir (éthique) d'ingérence est typique de cette ambiguïté." (Bensaïd, 1999a, p.164).

Podemos afirmar que a crítica de Bensaïd ao conjunto de novos usos instrumentais dos Direitos Humanos pela agência imperialista incide em uma das mais relevantes querelas concernentes à lida jurídica na contemporaneidade, qual seja, a definição de sentidos de conceitos e categorias amplas. Estas chaves abertas podem comportar, ao sabor da luta de classes, torções que justamente as neguem, que minem suas bases, e que sirvam à sua completa subversão, como nos casos aqui denunciados. 
Deste modo, em síntese e

"Em outras palavras, não se pode escamotear a relação que o discurso humanitário mantém com a política e a ideologia dominantes. Se o engajamento humanitário não se reduz a uma função de legitimação, dela também não escapa. Quando os donos do mundo falam em guerra ética ou de guerra humanitária, o caráter e os objetivos dessas guerras são escamoteados por trás da falsa evidência da intervenção compassiva. Disso resulta uma detestável confusão da moral e do direito, segundo a qual a pureza proclamada dos fins justificaria os mais abjetos meios." (Bensaïd, 2008c, 64)

Curiosamente, Bensaïd via tanto a Declaração de 1789 quanto a de 1948 não como declarações de paz, mas sim como um programa político de reivindicações, desta sorte se constituindo um programa de guerra (Bensaïd, 1989, p.268). E seu olhar para o mundo desde uma perspectiva da história enquanto fruto da luta de classe demandada apontar ser uma guerra, todavia, muito distinta daquela empenhada pelas nações imperialistas, empreendida pelos explorados e exploradas, oprimidos e oprimidas, como a batalha final que toma todas armas por válidas para libertação da humanidade. Uma guerra aos senhores.

\section{CONCLUSÕES}

Podemos deste modo concluir o presente texto expondo a percepção do quanto a obra de Daniel Bensaïd aparece atravessada pela discussão acerca dos Direitos Humanos. Da mesma sorte, mostra-se perceptível que tal qual o conjunto de outras elaborações teóricas que enfrentou em sua vida, também a que ora nos debruçamos se mostra marcada por uma preocupação política de caráter estratégico-revolucionário.

Entendemos assim que é justamente este indutor político profundo que impede sejam feitas leituras simplistas acerca do posicionamento do autor acerca dos Direitos Humanos. Não há, de modo algum, indícios em sua obra que possam sinalizar uma crítica negacionista à utilização da juridicidade para finalidades político-revolucionárias, da mesma sorte que se torna impossível apontar um 
endosso irrestrito aos Direitos Humanos na construção de uma alternativa radical de sociedade. São muitas as linhas, evidenciadas no presente escrito, que apontam o reconhecimento da importância política dos Direitos Humanos, sobretudo das liberdades e direitos civis, bem como dos Direitos Sociais. Tantas outras demonstram, de outro lado, seus limites estruturais e a impossibilidade de que pela consagração dos mesmos seja possível a construção de uma nova vida, em um novo mundo.

Deste modo, Daniel Bensaïd não se mostra nem um apologeta irrestrito dos Direitos Humanos, nem um cético e negacionista crítico de seu uso. Percebe as potências e limites que esta construção jurídico-política guarda no cerne de suas contradições.

Concluímos ainda que a definição de recorte trazida - a de voltar os olhos ao uso instrumental pela burguesia, tanto em sua expressão revolucionária na França, como por meio da agência imperialista contemporânea - nos ajuda a elucidar os pontos acima expostos nesta conclusão, destacando o modo como, da mesma sorte que devem explorados e exploradas, oprimidos e oprimidas impor tensões à sua utilização, também as classes proprietárias assim o fazem, buscando na discursividade defensora dos Direitos Humanos a legitimação de práticas que implicam em graves violações aos mesmos.

Outros temas ligados ao trato dos Direitos Humanos - assim como do direito em geral - na obra de Bensaïd comportam novos e permanentes olhares, para que de modo ainda mais complexificador se demonstre a riqueza e potência política da interpretação ansiosa por transformações que era a sua. Esperamos, assim, ter dado um passo na maior acolhida da obra do militante-filósofo não só no Brasil, como também no campo da pesquisa e estudo jurídicos.

\section{REFERÊNCIAS}

BENSAÏD, D. Contes et legendes de la guerre éthique. Paris: Textuel, 1999a.

Éloge de la politique profane. Paris: Albin Michel, 2008a. 
Da revolução inacabada à guerra ética: Bensaïd como defensor e crítico dos direitos humanos.

. Éloge de la résistance à l'air du temps. Paris: Textuel, 1999b.

. Espetáculo, fetichismo, Ideologia: um livro inacabado. Trad. Samuel Weimar Cavalcante e Silva. Fortaleza: Plebeu Gabinete de Leitura, 2013.

. Forças do comunismo. Trad. Eduardo Velhinho. In: LEITE, José Correa (Org.). Centelhas: marxismo e revolução no século XXI. São Paulo: Boitempo, 2017a.

. Jeanne, de guerre lasse. Paris: Gallimard, 1991.

. La pari mélancolique: métamorphose de la politique, politique des métamorphoses. Paris: Fayard, 2007a.

. La révolution et le pouvoir. Paris: Stock, 1976.

. Le scandale permanente. In: AGAMBEN, Giorgio et al. Démocratie, dans quel état? Paris: La fabrique, 2009.

. Le sourire du spectre: nouvel esprit du communisme. Paris: Michalon, 2000.

. Les dépossédés: Karl Marx, les voleurs de bois et le droit des pauvres. Paris: La fabrique, $2007 \mathrm{~b}$.

. "Maio de 68:" uma página na história mundial de lutas. Em Pauta, Rio de Janeiro, n. 21, p.80-99, 2008 b.

- Marx, o intempestivo: grandezas e misérias de uma aventura crítica (séculos XIX e XX). Trad. Luiz Cavalcanti de M. Guerra. Rio de Janeiro: Civilização Brasileira, 1999c.

Marxismo contra totalitarismo. Trad. Antonio José André. In: LEITE, José Correa (Org.). Centelhas: marxismo e revolução no século XXI. São Paulo: Boitempo, 2017b.

- Moi, la révolution: remembrances d'une bicentenaire indigne.Paris: Gallimard, 1989.

- 'Na e pela história.' Reflexões acerca de Sobre a questão judaica. Trad. Wand Caldeira Brant. In: MARX, Karl. Sobre a questão judaica. Trad. Nélio Schneider. São Paulo: Boitempo, 2010a.

- Os irredutíveis: teoremas da resistência para o tempo presente. Trad. Wanda Caldeira Brant, São Paulo: Boitempo, 2008c.

. Preface for the english edition: The Archipelago of Thousands Marxisms. In: BENSAÏD, D. Marx for our times: adventures and misadventures of a critique. Trad. Gregory Elliot. London/New York: Verso, 2002. 
. Tout est encore possible: entretiens avec Fred Hilgemann. Paris: La fabrique, 2010b.

. Trotskismos. Trad. Sérgio Vitorino. Lisboa: Combate, 2007c.

. Uma nova época histórica. Le site Daniel Bensaïd. Publicado em 1995. Disponível em: danielbensaid.org/IMG/pdf/1995_00_04_ db_b.pdf, acessado em 12.01.2020.

Textuel, 2003.

Un monde à changer: mouvements et stratégies. Paris: . Une lente impatience. Paris: Stock, 2004.

. Zur Judenfrage, uma crítica da emancipação política. Trad. Wand Caldeira Brant. In: MARX, K. Sobre a questão judaica. Trad. Nélio Schneider. São Paulo: Boitempo, 2010c.

- CORMAN, C. Le marranisme, un internationalisme réinventé: Entretien sur les mouvements d'émancipation d'hier et d'aujourd'hui. Le site Daniel Bensaïd, publicado em janeiro de 2002. Disponível em: danielbensaid.org/IMG/pdf/2002_01_01_ db_39.pdf, acessado em 01.01.2020.

1988.

. KRIVINE, A. Mai si! Rebelles et repentis. Paris: La brèche, . 1968, fins et suites. Paris: Lignes, 2008.

1968 .

.WEBER, H. Mai 68: une répétion générale? Paris: Maspero,

COMPARATO, F. K. A afirmação histórica dos direitos humanos. $6^{\mathrm{a}}$ ed. São Paulo: Saraiva, 2008.

DAVIS, A. Mulheres, raça e classe. Trad. Heci Regina Candiani. São Paulo: Boitempo, 2016.

EDELMAN, B. A legalização da classe operária. Trad. Marcus Orione (Coord.) et alii. São Paulo: Boitempo, 2016.

FONTES, V. O Brasil e o capital-imperialismo. Rio de Janeiro: EPSJ/ Fiocruz, 2010.

GARO, I. Un marxisme profane: Daniel Bensaïd, penseur de la propriété et de la démocratie. Lignes, n.32, Paris, p.39-46, 2o sem/2010.

GERAS, N. A actualidade de Rosa Luxemburgo. Trad. M. Resende. Lisboa: Antídoto, 1978.

HOBSBAWN, E. A era dos extremos: o breve século XX: 1914-1991. Trad. 
Marcos Santarrita. São Paulo: Companhia das Letras, 1995.

LACOSTE, T.; WAHNICH, S. Moi, la révolution', l'intensité offerte. Lignes, n.32, 2012/2, p.67-78, 2010

MACHADO, J. "Brésil". In: SABADO, F. (Org.). Daniel Bensaïd, l'intempestif. Paris: La Découverte, 2012.

MARX, K. Guerra Civil na França. Trad. Rubens Enderle. São Paulo: Boitempo, 2011.

. Luta de classes na França. Trad. Nélio Schneider. São Paulo: Boitempo, 2012.

. Os despossuidos: debates sobre a lei referente ao furto de madeira. Trad. Mariana Echalar e Nélio Schneider. São Paulo: Boitempo, 2017.

; ENGELS, F. Manifesto Comunista, Trad. Álvaro Pina. São Paulo: Boitempo, 2010.

O GLOBO. "Bolsonaro quer tipificar invasão de propriedade por MST e MTST como prática terrorista”. Publicado em 21.05.2018, disponível em: https://oglobo.globo.com/brasil/bolsonaro-quertipificar-invasao-de-propriedade-por-mst-mtst-como-praticaterrorista-22702521, acessado em 20.01.2020.

SEFERIAN, G. Direito do trabalho e ecossocialismo: primeiras aproximações. In: POLIDO, F. B. P.; BARBATO, M. R.; MOURA, N. das C. (Orgs.) Trabalho, tecnologias e os desafios globais dos direitos humanos. Rio de Janeiro: Lumen Juris, 2019a, p. 379-395.

Sobre o uso da miséria historiográfica e a relevância da investigação histórica na aplicação do Direito do Trabalho. In: $R$. Fac. Dir. UFG, Goiânia, v. 43, 2019b, p. 01-25. 